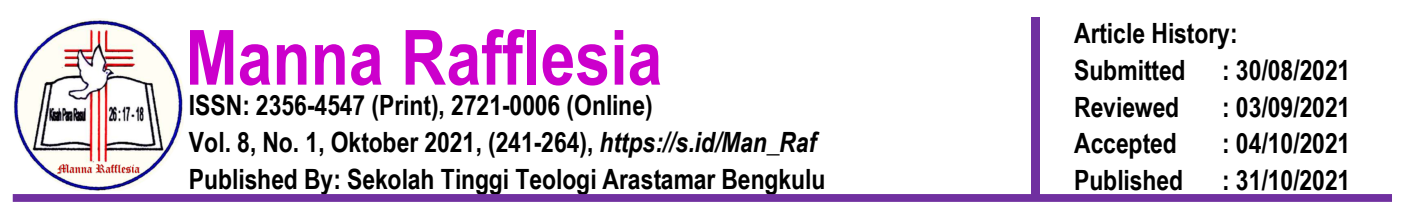

\title{
SIKAP DAN TANGGUNG JAWAB ORANG PERCAYA DALAM MENYIKAPI TEOLOGI IMANENSI
}

\author{
Yonatan Alex Arifianto $\left.{ }^{1 *}\right)$, Alfons Renaldo Tampenawas ${ }^{2}$, Deice Miske Poluan ${ }^{3}$ \\ Sekolah Tinggi Teologi Sangkakala ${ }^{1}$, Sekolah Tinggi Teologi Yerusalem Baru ${ }^{2}$, \\ Sekolah Tinggi Theologi Baptis Indonesia ${ }^{3}$ \\ *)Email Correspondence: arifianto.alex@sttsangkakala.ac.id
}

\begin{abstract}
The view of God which is reasoned logically and rationally brings the concept of God as an experience and not a transcendent person. Therefore, any form of immanence theology cannot be accepted as biblical teaching. Through a literature study approach, it is concluded that the existence of a transcendent and immanent God can counter the principles of immanence theology. God is present and actively participates in the world to give believers rest in the knowledge that no place or situation is too far away to be under God's protective hands. And moreover, God is present supernaturally and transcendentally far beyond human reason and logic, both in the form of religiosity that is built and one's relationship with the world.

Keywords: Immanence Theology, Transcendent, Believer's Attitude, Immanence.
\end{abstract}

Abstrak: Pandangan tentang Tuhan yang dinalar dengan logika dan rasional membawa konsep Tuhan adalah sebuah pengalaman dan bukan pribadi yang transenden. Oleh karena itu segala bentuk teologi imanensi tidak dapat diterima sebagai ajaran Alkitabiah. Melalui pendekatan studi literatur disimpulkan bahwa keberadaan Tuhan yang transenden dan imanen dapat mengcounter prinsip dari teologi imanensi. Tuhan hadir dan secara aktif berpartisipasi dalam dunia untuk memberi orang percaya ketenangan dalam pengetahuan bahwa tidak ada tempat atau situasi yang terlalu jauh untuk berada di bawah tangan perlindungan Tuhan. Dan terlebih Tuhan hadir secara supranatural dan transenden jauh melebihi akal dan logika manusia baik dalam bentuk religiusitas yang dibangun dan hubungan atau relasi seseorang dengan dunia.

Kata Kunci: Teologi Imanensi, Transenden, Sikap orang percaya, Imanen.

\section{PENDAHULUAN}

Kajian tentang Pribadi pencipta atau Tuhan menjadi pembahasan dan topik yang sangat menarik serta membuat banyak orang senantiasa bertanya, siapa dan apa Tuhan sebenarnya? Terlebih sikap keingintahuan manusia terhadap keberadaan Tuhan. Bahkan pemikiran manusia ingin mempersoalkan hubungan atara Tuhan dengan manusia dan alam semesta. Sebab setiap manusia baik seorang yang memiliki kepercayaan (theis) atau seorang yang tidak memiliki 
kepercayaan (atheis). Manusia selaku personal sebagai ciptaan bahkan sebagai pribadi menyadari dan mengusahakan untuk sesuatu yang kekal dan berusaha untuk memikirkan sesuatu yang berdaulat, baik sesuatu yang personal ataupun impersonal. Hal itu mengungkapkan manusia ingin lebih sungguh mengenal dan hidup kepada pribadi yang supranatural atau ilahi, yang berkaitan dengan keberadaan hubungan antara manusia dengan Pencipta. ${ }^{1}$ Sebagai sikap ketundukan dan menerima ada pencipta yang berotoritas.

Topik tentang Tuhan dibicarakan karena adanya kepercayaan manusia terhadap pribadi yang lebih tinggi yang sudah ada sejak awal. Bahkan pribadi itu menjadi icon atau sesembahan, sehingga memberikan pengaruh yang kuat dalam kehidupan manusia. ${ }^{2}$ Namun ada beberapa problem konsep tentang Tuhan, yaitu apakah Tuhan berada di mana-mana? Apakah Tuhan yang transenden berada jauh dari alam semesta yang tak terlihat secara fisik?. Persoalan ketuhanan ini tidak pernah terselesaikan sebab memiliki banyak arti dan maksud yang muncul dalam konteks yang berbeda. Sehingga menghadirkan perspektif yang menekankan imanensi dan transendensi. ${ }^{3}$

Konsep kemahahadiran, pengetahuan dan keagungan Tuhan menjadi suatu hal yang terus dikaji dalam mengemukakan teologi kehadiran Allah bagi manusia. Namun ada yang membingungkan dari segi imanensi adalah Tuhan terlihat hadir di tempat-tempat yang tidak menyenangkan seperti senjata pembunuh dan tradisitradisi keagamaan yang memungkinkan kehadiran setan atau roh jahat.

\footnotetext{
1 Kevin Tonny Rey, "Konstruksi Teologi Dalam Konteks Reposisi Pemikiran Warga Gereja," EPIGRAPHE: Jurnal Teologi Dan Pelayanan Kristiani 2, no. 1 (2018): 1-13.

2 tesra Murnita, "Diskursus Transenden Dan Imanen Tuhan Menurut Ibn 'Arabi" (Universitas Islam Negeri Sultansyarf Kasim Riau, 2020), 1.

3 Hadi Vakili, "Fuzzy Epistemology From View Point of Mystical Theology," Kanz Philosophia A Journal for Islamic Philosophy and Mysticism 2, no. 1 (2012): 27-44.
} 
Bagaimana bisa Tuhan hadir di dalam hal yang buruk? Adanya musibah dan bencana menjadi pola pikir bahwa Tuhan juga menyetujui, namun hal itu akan menjadi suatu keadaan dimana Allah tidak diterima karena konsep tersebut. ${ }^{4}$

Tidak dapat dipungkiri bahwa orang percaya masa kini menganggap Tuhan yang imanen. ${ }^{5}$ Karena Tuhan yang imanen adalah Tuhan yang hadir dalam diri setiap manusia, setiap makhluk hidup dan dalam alam semesta. ${ }^{6}$ Namun pengertian Tuhan yang hadir dihilangkan setiap aspek transendensi Allah dan bahaya teologi ini yaitu mereduksi kemahakuasaan Allah yang transenden ke dalam hal-hal yang berpusat pada logika dan kognitif. Oleh sebab itu peneliti memfokuskan konsep teologi imanensi dan pengaruhnya terhadap orang kristen masa kini. Selanjutnya timbul persoalan adanya perbedaan konsepsi tentang Tuhan yang diwarisi dari Perjanjian Lama, Bapa gereja mula-mula, Abad pertengahan, para teolog Kristen dipenuhi dengan misteri dan keanehan tentang Tuhan ditambah dengan ketidakcukupan bahasa manusia dan kategori manusia untuk menggambarkan Tuhan yang seutuhnya. ${ }^{7}$ Menjadi persoalan tersendiri dalam menggambarkan Tuhan.

Pemikiran imanen membahas kedekatan manusia dengan Allah namun menghilangkan pribadi Allah yang transenden sehingga membawa sikap kepada akal dan logika manusia lebih ditonjolkan dan menghilangka sifat kemahakuasaan dan kebesaran Allah. Sehingga supranatural Allah tidak diterima di dalam lingkup

\footnotetext{
${ }^{4}$ Chris H. Ransford, "Immanence or Transcendence? A Mathematical View," in Proceedings of Conferences on the Dialogue between Science and Theology, 2016, 21-26, https://doi.org/10.18638/dialogo.2015.2.2.1.

5 Chris H. Ransford, "Immanence or Transcendence? A Mathematical View.

6 Suhermanto Ja'far, "Aku Dalam Tuhan: Implikasi Teologi Proses Pada Era Kontemporer," Ulumuna 16, no. 2 (2012): 347-74.

7 Charles Thomas Lewis Jr, "Far and Near: Christian Worship of the Transcendent and Immanent God of Wonders," 2015, 23.
} 
teologi imanensi. Hal itu dapat memengaruhi sikap dan prilaku seseorang tentang Allah.

Berkaitan dengan topik sikap dan tanggung jawab orang percaya dalam menyikapi teologi imanensi telah diteliti oleh Jokhana dalam tulisannya yang berjudul Konsep Transendensi dan Imanensi Allah di dalam Teologi Schleiermacher. ${ }^{8}$ Kesimpulan dari penelitian tersebut adalah bahwa Allah ditempatkan sejajar dengan dunia ini. Pemahaman Allah yang dibawa oleh Schleiermacher tidak lagi dibangkitkan dari keterlibatan dengan firman Tuhan sebagai wahyu Allah, melainkan adalah suatu bentuk religiusitas yang dibangun dan hubungan atau relasi seseorang dengan dunia. Begitu juga dengan Sonny Eli Zaluchu melakukan penelitian terhadap Perkembangan Teologi Kristen Di Dekade Pertama Abad XXI yang mengkategorikan teologi imanensi sebagai kecenderungan untuk menyimpulkan segala sesuatu dengan bertitik tolak sematamata pada alam dan natur manusia yakni akal budi manusia. Hal itu membawa kepada kecenderungan sikap dan prilaku manusia untuk mempertanyakan transendensi Allah dan sifat-sifat supranatural-Nya. Hal ini terjadi karena manusia sudah dipengaruhi oleh kemajuan berpikir sainstik dan berpusat pada diri sendiri. ${ }^{9}$ Berdasarkan kedua penelitian tersebut masih ada hal-hal yang belum diteliti yaitu tentang Sikap dan tanggung jawab orang percaya dalam menyikapi teologi imanensi. Oleh sebab itu artikel ini akan meneliti dan membahas tentang topik tersebut supaya menjadi jawaban bagi kekristenan masa kini.

8 Jokhana, "Konsep Transendensi Dan Imanensi Allah Di Dalam Teologi Schleiermacher" (Sekolah Tinggi Teologi Amanat Agung, 2006).

9 Sonny Eli Zaluchu, "Perkembangan Teologi Kristen Di Dekade Pertama Abad XXI," Bunga Rampai Jenis-Jenis Teologi Pada Periode 1990-2009, 2009. 


\section{METODE}

Artikel ini berupa penelitian kualitatif deskritif dengan pendekatan studi literatur. ${ }^{10}$ Penggalian makna Teologi imanensi yang berkaitan dengan konsep Alkitabiah sebagai dasar dalam membangun pemahaman pentingnya orang Kristen dalam bersikap terhadap teologi imanensi. Selain itu penulis juga menggunakan data dari berbagai buku dan artikel jurnal untuk mendapatkan informasi deskriptif tentang makna dan juga pengaruh serta dampak teologi imanensi. Penulis mendeskripsikan sikap dan tanggung jawab orang percaya terhadap teologi imanensi dalam kehidupan kristen yang berkaitan dengan kondisi kekristenan dalam aplikasi hidup sehari-hari.

\section{HASIL}

Penelitian tentang sikap dan tanggung jawab orang percaya dalam menyikapi teologi imanensi memberikan hasil pemikiran bagi orang percaya untuk bersikap kritis dan mampu menalar adanya teologi yang tidak sesuai dengan kebenaran Alkitab. Oleh karena itu orang percaya dapat memahami latar belakang sejarah dan munculnya teologi imanensi dan dampak bagi konsep Allah dalam dogmatika Allah. Sehingga orang percaya dapat menyatakan diri menolak keberadaan dan ajaran teologi imanensi. Hasil penelitian ini mendeskripsikan konsep serta ajaran teologi imanensi dalam versi imanentisme modern, yang menjelaskan bagaimana teologi itu muncul dan berkembang dari dasar Alkitab. Melalui hal tersebut orang percaya mengetahui kekuatan dan kelemahan doktrin teologi Imanensi.

10 Umrati and Hengki Wijaya, Analisis Data Kualitatif Teori Konsep Dalam Penelitian Pendidikan (Sulawesi Selatan: Sekolah Tinggi Theologia Jaffray, 2020), 12. 


\section{PEMBAHASAN}

Doktrin imanensi menyatakan bahwa yang ilahi meliputi atau dimanifestasikan di dunia material. Pandangan ini banyak dianut oleh beberapa filsuf dan teori metafisika tentang kehadiran ilahi. Imanensi biasa diterapkan dalam konsep monoteistik, panteistik, pandeistik dan panenteistik. Beragam konsep tersebut percaya bahwa oknum supranatural meresap ke dunia. Pandangan ini sering dikontraskan dengan doktrin transendensi, di mana oknum yang ilahi dipandang berada di luar dunia material. Secara terminologi kata "imanensi" berasal dari akhir kata Latin "imanen" yang artinya to stay in (tetap di, tetap). ${ }^{11}$ Selanjutnya imanensi berarti hadir sebagai bagian alami dan permanen dari sesuatu. Secara terminologis imanensi dipahami sebagai melekatnya pribadi Allah pada sesuatu yang dimiliki oleh Tuhan yang imanen, baik hadir disetiap pribadi manusia, makhluk hidup dan alam semesta. Pemahaan imanensi diawali dari sejarah bersamaan adanya ajaran yang menekankan tidak adanya pencipta atau disebut atheisme dan pantheisme. Namun, istilah transendensi merujuk pada situasi dan keadaan tak terlampaui atas batas tertentu, umumnya batas material atau fisik, sedemikian hingga terkait erat dengan ajaran theisme. ${ }^{12}$

\section{Latar Belakang Sejarah Munculnya Teologi Imanensi Dan Imanentisme Modern}

Rasionalitas tentang teologi imanensi pertama kali diformulasikan pada khazanah filsafat Prancis kontemporer. Awal mula teologi ini berangkat dari penerimaan atas filsafat Hegel oleh para filsuf Prancis pada abad ke 20 dengan pemikiran bahwa rasio selalu ingin mencapai yang absolut sebab rasio tidak

11 Dictionary.com is the world's leading digital Dictionary, "Immanence," Dictionary.com, 2021, https://www.dictionary.com/browse/immanence.

12 Martin Suryajaya, Imanensi Dan Transendensi (Jakarta: Penerbit AksiSepihak, 2009), 1. 
dipahami sebagai subyek tertentu yang dimiliki orang tertentu melainkan sebagai suatu inteligensi yang mengatasi individu, suatu subyek absolut yakni Roh. Hal itu bermula dari Kojève hingga Hyppolite serta bagaimana keduanya membangun matriks dasar dari problem dogmatis imanensi kontemporer. Dari kontribusi kedua sosok filsuf tersebut pada era filsafat Prancis tahun 60-an, dapat dilihat sebagai suplemen, bagaimana wacana imanensi telah ada dari pemikiran Hegel.. Dengan demikian, apa yang telah dilakukan memiliki tujuan dan maksud untuk mengakui Hegel sebagai bapak imanensi filsafat Prancis kontemporer. ${ }^{13}$

Problem imanensi terdapat di filsafat Yunani, sebab filsafat Yunani adalah filsafat yang beraliran imanensi, karena filsafat tersebut demikian sejauh dikontraskan dengan filsafat kristiani yang adalah filsafat transendensi. ${ }^{14}$ Ajaran filsafat Yunani menekankan hierarki "ada" baik Plato, Aristoteles dan Neoplatonisme, memberikan topografi kerangka "imanensi."15 Pandangan tersebut selaras dengan natur dari ajaran filsafat pragmatisme, rasionalisme dan empirisme yang kembali mendapat tempat dan mempunyai kecenderungan untuk menyimpulkan segala sesuatu dengan bertumpuh pada alam dan sifat dari natur manusia yaitu pemikiran atau akal budi. Dan inilah yang dimaksud dengan teologi imanensi. $^{16}$

Abad ke-20 telah menyaksikan beberapa gerakan yang sangat menekankan imanensi ilahi. Namun pandangan liberalisme tradisional, yang meliputi berbagai taraf, telah memahami Allah sebagai pribadi yang imanen di dalam dunia ini. Sampai taraf yang cukup luas, perbedaan di antara fundamentalisme dengan

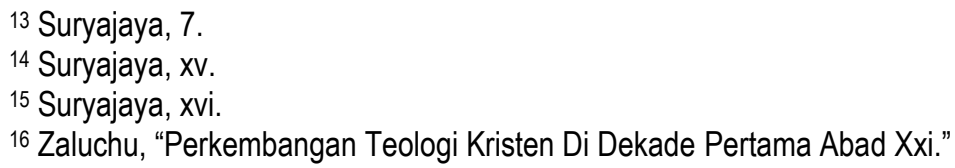


liberalisme merupakan perbedaan dalam pandangan hidup. ${ }^{17}$ Golongan konservatif berkarya dalam lingkup supra-alami. Allah diam di luar dunia dan secara berkala turun tangan dalam proses-proses alamiah melalui berbagai mukjizat. Orang konservatif melihat realitas sebagai menempati lebih dari satu tingkat. Sebaliknya, orang liberal, cenderung memandang realitas ini sebagai menempati satu tingkat saja. Tidak ada alam adi-kodrati di luar alam yang alamiah ini. Allah berada di dalam alam dan bukan di luar alam tersebut. ${ }^{18}$

Sekalipun liberalisme bukan naturalisme, namun keduanya mempunya trend atau model yang sama. Terdapat gaya yang lebih condong beranggapan bahwa Allah atau pribadi Sang Pencipta hanya bertindak lewat proses-proses alam dan sama sekali tidak lewat hubungan terputus yang radikal dengan alam ini. Golongan liberal sangat suka menerima landasan atau konsep evolusi sebagai contoh dari karya Allah. Dalam evolusi mereka melihat Allah sedang melaksanakan tujuan-Nya dengan menggunakan sarana alamiah. Menurut pandangan liberal, tidak ada yang sekular, karena Allah berkarya di mana-mana dan melalui segala sesuatu yang terjadi. Friedrich Schleiermacher mengartikan mukjizat sebagai nama keagamaan untuk peristiwa. Setiap peristiwa, bahkan yang paling wajar dan biasa, menjadi satu mukjizat. ${ }^{19}$ Selanjutnya pandangan konservatif melihat karya Allah secara khusus dalam berbagai tindakan yang luar biasa, orang liberal melihat Allah berkarya di mana-mana. Kelahiran Yesus dari seorang perawan adalah penting bagi golongan konservatif sebagai suatu bukti karya Allah yang khusus. Sebaliknya, seorang liberal menyatakan kelahiran Yesus dari seorang perawan itu mukjizat, setiap kelahiran merupakan mukjizat. Orang-

${ }^{17}$ Millard J. Erickson, Teologi Kristen Volume 1 (Malang: Gandum Mas, 2014), 489.

${ }^{18}$ Erickson, 489.

19 Erickson, 490. 
orang konservatif pada akhir abad ke-19 dan awal abad ke-20 telah dengan gigih menolak teori Darwin mengenai evolusi, karena kelihatannya menjadikan penciptaan oleh Allah suatu ajaran yang tidak berguna. Akan tetapi bagi pandangan liberal tidaklah demikian, evolusi tidak mencegah aktivitas ilahi, justru aktivitas itu sudah ada sebelumnya. Golongan konservatif beranggapan bahwa alam semesta harus memiliki satu penyebab saja, yaitu Allah yang menyebabkan semuanya secara langsung. ${ }^{20}$

Frederic Schleiermacher mewakili pandangan liberalisme Protestan modern yang membongkar transendensi Tuhan. Alih-alih membayangkan Tuhan sebagai yang transenden selain ciptaan, Schleiermacher memeluk gagasan bahwa Tuhan harus dialami secara imanen di dalam individu. ${ }^{21}$ Menurut Schleiermacher, konsep teologi merupakan kerja keras dalam menganalisis pengalaman kesadaran beragama yang bermuatan keyakinan manusia yaitu perasaan ketergantungan kepada yang mutlak atau kekal. Namun hakikat sejati agama adalah kesadaran langsung dari Ketuhanan seperti yang ditemukan di dalam diri manusia dan di dunia. ${ }^{22}$ Friedrich Schleiermacher juga melihat imanensi Allah dalam perasaan agamani manusia. ${ }^{23}$ Sehingga akal manusia telah diangkat ke atas takhta dan menjadi fokus dari segala hal teologi. Konsep tersebut mengkritik iman tradisonal dan berusaha mendasarkan teologi pada pengalaman manusia, bahwa segala agama berakar dan identik dengan suatu pengalaman esensial ke arah pencapaian

20 Erickson, 490.

21 Robert K Johnston, "God in the Wasteland: The Reality of Truth in a World of Fading Dreams" (JSTOR, 1995), 111.

27.

22 Lewis Jr, "Far and Near: Christian Worship of the Transcendent and Immanent God of Wonders,"

${ }^{23}$ Andreas Anangguru Yewangoe, Allah Mengizinkan Manusia Mengalami Dirinya (Jakarta: BPK Gunung Mulia, 2018), 6. 
kemanusiaan sejati. ${ }^{24}$ Hal tersebut menjadikan segala atribut yang dikenakan kepada transendensi Allah dipandang sebagai perasaan ketergantungan mutlak dengan Allah. Dengan kata lain berbicara tentang Allah senantiasa berbicara tentang pengalaman manusia mengenai Allah. Pernyataan macam ini tidak menggambarkan Allah di dalam Diri-Nya sendiri, tetapi mengenai suatu cara tertentu dari pengalaman tentang Allah. Pandangan ini menekankan dan berpusat pada manusia dan bukan kepada Allah. ${ }^{25}$

Versi imanentisme yang lain adalah versi Paul Tillich dalam banyak hal Tillich melihat dirinya sedang berdiri di perbatasan antara berbagai kelompok dan aliran. Khusus memandang diri menempati kedudukan di tengah- tengah golongan liberal dan neo-ortodoks. Dalam banyak hal, gagasan yang paling istimewa adalah doktrin tentang Allah. Tillich tidak menganggap Allah sebagai suatu oknum di antara sekian banyak oknum lainnya. Dalam teisme konvensional, Allah merupakan pribadi yang mahatinggi, yang memiliki derajat agung, yang tak terbatas, namun tetap satu oknum dibandingkan dengan oknum-oknum lain yang terbatas. Allah berada di luar mereka, dan mereka berada di luar Allah. ${ }^{26}$ Namun bagi Paul Tillich, Allah bukan sekadar suatu oknum yang ada, Allah adalah keberadaan itu sendiri, atau sumber keberadaan. Allah adalah kekuatan internal yang menyebabkan keberadaan segala sesuatu. Sedangkan semua oknum yang terbatas, mempunyai keberadaan, Allah tidak. Sekalipun pernyataan ini kedengarannya merendahkan Allah, tetapi sebenarnya tidak demikian. Beberapa orang telah mengira bahwa Tillich seorang atheis karena mengatakan bahwa Allah tidak mempunyai keberadaan. Pernyataan Tillich bahwa Allah tidak

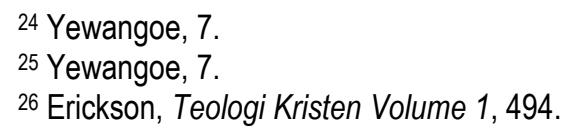


mempunyai eksistensi bukanlah merendahkan Allah, namun merupakan suatu pujian. Ketika Tillich mengatakan bahwa Allah tidak mempunyai keberadaan, artinya Allah tidak sekedar ada, melainkan Allah merupakan sumber keberadaan segala sesuatu yang ada. ${ }^{27}$ Pandangan Tillich menekankan bahwa Allah berada dalam segala sesuatu, walaupun Allah merupakan sumber keberadaan tetap obyek, namun Allah tidak dapat dikenal dan tidak mungkin ada sebelum ada hal-hal lain. ${ }^{28}$ Allah dinyatakan sebagai "Being itself” ketika esensi dan eksistensi tidak ada gap di antara keduanya. Ini berbeda dengan makhluk manusia yang selalu menyisakan gap antara esensi dan eksistensinya. ${ }^{29}$

\section{Dasar Alkitab Pemikiran Dokrin Teologi Imanensi}

Kehadiran ilahi dan imanensi-Nya dapat dilihat pertama kali dalam karya Penciptaan. Allah mendekati dunia manusia, dunia yang berada dalam keadaan kacau dan mulai menciptakan serta mengatur. Enam hari Allah menciptakan planet yang indah dan di tengah semua keindahan Allah menempatkan manusia. Manusia pertama mengetahui imanensi ilahi, karena Sang Pencipta berbicara setiap hari. ${ }^{30}$ Imanensi Allah merupakan istilah tentang kehadiran dan segala yang dilakukan Allah di dalam alam semesta, terhadap prilaku, watak dan hingga perjalanan sejarah. ${ }^{31}$ Alkitab menunjukkan kehadiran Allah dalam alam semesta (Yer. 23: 24). ${ }^{32}$

Tulisan Para Rasul di Perjanjian Baru menyatakan bahwa Allah tidak jauh dari manusia, sebab di dalam Allah manusia hidup, bergerak dan ada (Kis. 17: 27-

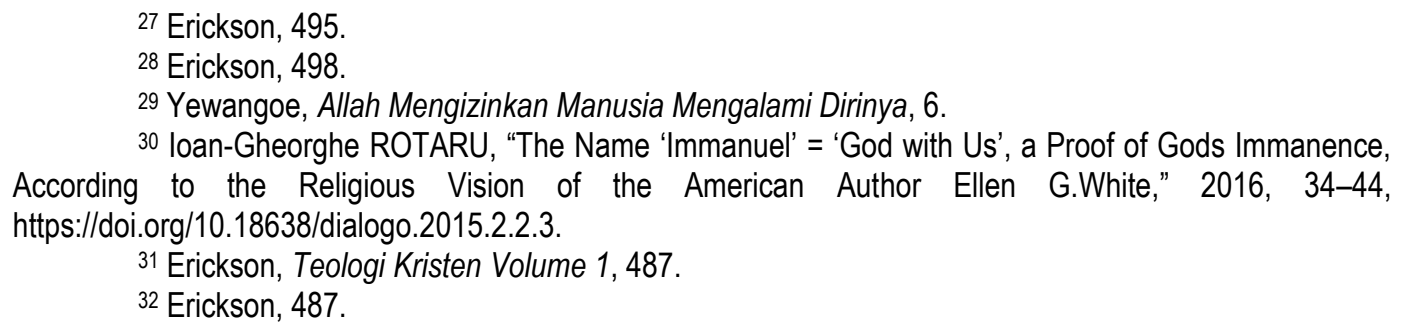


28). Selanjutnya roh Allah menciptakan dan menopang segala sesuatu dan bergantung pada Tuhan. ${ }^{33}$ Perjanjian Baru juga menunjukkan bahwa Allah berinkarnasi ketika firman menjadi daging. Allah hidup di antara manusia, mengajar dan menyembuhkan. Namun setelah Yesus naik ke surga, Allah mengutus Roh-Nya untuk tinggal di antara umat-Nya. Orang percaya menjadi bait-Nya dan Tuhan menjadi Penghibur serta Pembimbing. Perjanjian Allah dengan umat-Nya untuk memberikan hati yang baru dan memimpin dengan RohNya sehingga dapat hidup di jalan-Nya. Konsep tersebut menunjukkan pada Allah yang tidak jauh (Kis. 17: 27). ${ }^{34}$

Kehadiran Allah dalam manusia dituliskan dalam kitab-kitab puisi, di antaranya dalam kitab Ayub (Ayb. 27: 3; 33: 4; 34: 14-15) dan Mazmur 104: 2930. Teologi pekerjaan Allah dalam penciptaan di Kitab Kejadian, memfokuskan keterlibatan Allah dalam membentuk atau menciptakan dunia. ${ }^{35}$ Penyataan Allah dalam kitab Kejadian 1: 2 Roh Allah digambarkan sebagai melayang-layang di atas permukaan air, selanjutnya dalam Kejadian 2: 7 dinyatkan bahwa Allah menghembuskan napas hidup ke dalam manusia dan manusia menjadi makhluk yang hidup. Kemudian Yesaya 63: 11, Mikha 3: 8, dan Hagai 2: 5 mencatat bahwa Roh Allah tinggal di dalam dan bersama-sama dengan umat-Nya. Selain itu ada juga berbagai rujukan Alkitab yang mengemukakan bahwa apa pun yang terjadi di alam ini merupakan tindakan Allah dan berada di bawah pengawasanNya. Pengiriman sinar matahari dan hujan, pemeliharaan dan perlindungan burung-burung di udara, serta hal mendandani bunga bakung di padang, semuanya diakui berasal dari Bapa (Lih. Mat. 5: 45; 6: 25-30; 10: 29-30). Pribadi Tuhan

\footnotetext{
33 Erickson, 387.

${ }^{34}$ Harold R. Eberle, Kekristenan Tanpa Belenggu (Yogyakarta: Yayasan Andi, 2015), 140.

35 Erickson, Teologi Kristen Volume 1, 487.
} 
yang aktif berbagai aktivitas di dunia sebagai konsep Allah bekerja dalam polapola tetap alam semesta. Allah adalah Allah atas alam dan atas hukum alam. Bahkan apa yang pada umumnya dianggap sebagai peristiwa alam biasa dipandang sebagai tindakan Allah, karena alam dan Allah tidaklah terpisah. Allah hadir di mana-mana, bukan hanya berbagai kejadian yang spektakuler di dalam pergerakan manusia. Konsep yang meyakini bahwa keberadaan Allah ada karena sesuatu yang terjadi di alam semesta yang secara natur telah ada. Hal itu memberi pemahaman bahwa garis pemisah di antara Allah dengan manusia atau Allah dengan dunia tidak boleh dibuat dengan terlalu tajam. ${ }^{36}$

Banyak konsep imanensi Allah ditekankan dan dikembangkan, semakin dekat pula pemahaman tersebut bergerak menuju ke panteisme dan bukan teisme. Artinya, pada saat transendensi Allah yaitu kedudukan-Nya yang terlepas dari ciptaan kurang diutamakan. Allah kurang bersifat pribadi dan persekutuan pribadi manusia dengan Allah menjadi makin berkurang. Sekalipun imanensi dalam bentuk yang ekstrem mirip dengan panteisme, tetap masih ada perbedaan di antara kedua pandangan itu. Dalam pendapat bahwa Allah itu imanen, alam ini tidak memiliki kedudukan independen. Sebagaimana telah diungkapkan bahwa alam tidak transenden terhadap Allah. ${ }^{37}$ Suatu teologi imanensi bahwa Allah ada di dalam semua bagian dari alam semesta yang diciptakan. ${ }^{38}$ Sedangkan konsep imanensi spiritual dibuat menjadi pengalaman sehari-hari yang nyata. Dimana Tuhan didekatkan oleh hal yang tak terduga. ${ }^{39}$ Konsep imanensi mengacu pada

36 Erickson, 488.

37 Erickson, 147-48.

38 A Eckardt, "Roy, Menggali Ulang Yesus Sejarah: Kristologi Masa Kini" (Jakarta: BPK Gunung Mulia, 1996), 316.

39 Joseph Webster, "The Immanence of Transcendence: God and the Devil on the Aberdeenshire Coast," Ethnos 78, no. 3 (September 2013): 380-402, https://doi.org/10.1080/00141844.2012.688762. 
bidang subjek, bahwa Tuhan hadir hanya realisasi dari pengalaman, sedangkan transendensi mengacu pada apa yang ada di luar subjek, seperti "dunia luar" atau "yang lain." Dalam tradisi istilah "transendensi" mengacu pada apa yang melampaui bidang kesadaran yang melekat pada subjek. ${ }^{40}$ Lukito dikutip oleh Zaluchu mengungkapkan ada dampak dari pengaruh teologi imanensi, sehingga menimbulkan kesan bahwa Allah yang luar biasa dalam konsep transenden menjadi tak bermakna dan ironisnya Pribadi pencipta lebih banyak mengejahwantahkan pribadi-Nya di dalam kehidupan setiap manusia, dan keberadaan pencipta dianggap masuk dan menyerap serta berada di dalam seluruh alam. $^{41}$ Konsep Allah Yang maha kuasa tersingkirkan karena Allah yang transenden dan supranatural tidak dapat diterima dalam teologi yang mengutamakan rasio manusia. Manusia modern memiliki kemampuan dalam rasional, empirik dan pragmatis, memiliki kecenderungan memaknai atau mengartikan Tuhan. ${ }^{42}$ Manusia mengidentifikasi substansi Tuhan dengan sebagian atau keseluruhan dari dunia hingga imanensi ilahi menolak transendensi ilahi. ${ }^{43}$ Prinsip imanensi tidak lain adalah generalisasi pengalaman yang mengecualikan transendensi Keberadaan. ${ }^{44}$

\section{Kekuatan Dan Kelemahan Doktrin Teologi Imanensi}

Alkitab mencatat dalam Perjanjian Baru, adanya wahyu Allah di dalam Kristus adalah inkarnasi imanensi. Yesus Kristus adalah Allah yang Imanuel, Tuhan beserta kita. Di dalam Kristus, Tuhan menyatakan diri sebagai pribadi dan

40 Daniel W Smith, "Deleuze and Derrida, Immanence and Transcendence: Two Directions in Recent French Thought," in The Proceedings of the Twenty-First World Congress of Philosophy, vol. 11, 2007, 123-30.

41 Zaluchu, "Perkembangan Teologi Kristen Di Dekade Pertama Abad Xxi."

42 Zaluchu.

43 Xaverius Chandra, Bahan Ajar Filsafat Ketuhanan (Surabaya: Faculty of Philosophy, 2017), 10.

44 Giorgio Agamben, Absolute Immanence (na, 1999), 157. 
dekat dengan umat-Nya. Meskipun Kristus dekat dan dengan umat-Nya, secara ontologis Yesus tetap berbeda dari ciptaan, penguasa berdaulat atas ciptaan dan hakim terakhir bagi umat manusia yang berdosa. ${ }^{45}$ Pandangan terhadap teologi ini perlu hati-hati, sehingga perlu konsep kehadiran Allah dalam hidup manusia. Pikiran bahwa Allah hanya pengalaman dan sama dengan ciptaan yang berbaur sebagai ciri khas dari ajaran imanensi. Maka hal itu membawa manusia tidak memiliki pegangan akan adanya Tuhan yang peduli dan kebesaran Tuhan yang transendensi. Pandangan teologi imanennsi menekankan akan akal dan rasio manusia dalam menakar dan menilai Tuhan, memberikan problem dalam iman kepada Tuhan. Tuhan yang hadir dalam manusia dilihat dari sisi pengalaman yang harus dapat dibuktikan sehingga mengakibatkan kehidupan manusia secara tidak sadar dibentuk oleh sains dan teknologi hal ini tidak dapat diperdebatkan sebab sudah menjadi realita. ${ }^{46}$ Hal itu sangat bertolak belakang tentang nilai penting agama dalam mencari pribadi Tuhan menjadi sebuah kesadaran akan Allah yang sempurna. Ini menjadi point penting bahwa manusia mengetahui sifat kekekalan Tuhan. $^{47}$

Kajian yang bisa mengakibatkan orang percaya untuk memahami secara salah terhadap ajaran imanensi Allah. Pertama, pantheisme. Pemeluk atau penganut cara pandang ini percaya bahwa setiap ciptaan merupakan Allah atau bagian dari Allah itu sendiri, dan juga ditegaskan bahwa Allah adalah ciptaan. Jadi, menurut pandangan ini, Allah dan ciptaan adalah selaras atau setara. Hal ini berbeda dengan ajaran Alkitab yang mempercayai Allah hadir dalam semua 6.

${ }^{45}$ Lewis Jr, "Far and Near: Christian Worship of the Transcendent and Immanent God of Wonders,"

46 Wessel Bentley, "Balancing the Transcendence and Immanence of God in Nürnberger's Theology," Verbum et Ecclesia 39, no. 1 (2018): 1-5.

${ }_{47}$ Paul Avis, Ambang Pintu Teologi, 7th ed. (Jakarta: BPK Gunung Mulia, 2017), 66. 
ciptaan-Nya, Allah itu berbeda natur (distinct) dengan ciptaan-Nya. Kedua, deisme. Pemeluk keyakinan deisme memiliki pengertian bahwa Allah itu berbeda dari ciptaan-Nya, namun tidak mengakui bahwa Allah berperan aktif dalam ciptaan. Kelompok deisme percaya bahwa setelah Allah menciptakan semesta, Allah memberi kebebasan kepada alam semesta bekerja dengan sendirinya melalui hukum alam yang tidak membutuhkan pengawasan dari Allah. Hal ini pastinya sangat berbeda dengan keyakinan orang Kristen yang memiliki iman kepada Allah dengan mempercayai bahwa Allah juga secara aktif menopang terlebih lagi memelihara ciptaan-Nya. Teologi imanensi menyatakan bahwa Tuhan hanya berperan menciptakan saja, maka hilangnya kekaguman religius dan kesadaran akan hadirat ilahi adalah produk sampingan dari kesalahan dalam pemikiran religius modern yang dimulai dengan memikirkan Tuhan secara imanen tanpa landasan transenden. ${ }^{48}$ Teologi hanya sebuah penelitian agama, konsep Tuhan hadir hanya dikembangkan dalam sebuah perasaan dan pengalaman. ${ }^{49}$ Hal itu berbeda dengan ajaran Kristen tentang kehadiran Tuhan yang memberikan sukacita dan membawa kehidupan. ${ }^{50}$ Oleh karena itu bila kehadiran Allah kepada manusia hanya sebuah perasaan dan pengalaman, maka hal itu dapat membuat manusia bertindak dan berprilaku semaunya untuk merusak alam, karena pola pikir manusia bahwa Tuhan dianggap hanya pribadi yang menciptakan dan tidak memelihara.

48 Lewis Jr, "Far and Near: Christian Worship of the Transcendent and Immanent God of Wonders," 22.

49 Tony Lane, Runtut Pijar (Jakarta: BPK Gunung Mulia, 2016), 199.

50 Ransford, "Immanence or Transcendence? A Mathematical View." 


\section{Sikap Dan Tanggapan Terhadap Teologi Imanensi}

Teologi imanensi sejatinya telah menyimpang dan tidak sesuai dengan Alkitab. Maka orang percaya perlu menolak dengan tegas konsep teologi imanensi. Sebab teologi imanensi membawa pemikiran manusia ke dalam cara berpikir yang mengkerdilkan kuasa Tuhan yang transenden. Bahkan membawa manusia untuk dapat menalar Tuhan dengan logika sehingga peran iman yang diajarkan Tuhan dalam setiap ajaran di Alkitab tidak menjadi acuan dan tuntunan hidup.

Kekristenan mengajarkan bagaimana orang percaya untuk memiliki keyakinan yang hakiki terhadap apa yang telah Yesus lakukan bagi keselamatan manusia. Karena Yesus dalam sejarah sebagai pribadi Tuhan yang imanen. Sehingga manusia berbicara bukan dalam narasi metafisik saja tetapi adanya iman yang secara teologis mengenal keberadaan-Nya yang jauh lebih hebat dari apa yang telah diciptakan-Nya. Kehadiran-Nya yang supranatural bagi semua orang tanpa dibatasi oleh ruang dan waktu, Yesus mengajarkan bahwa Allah hadir dalam partisipasi yang bertanggung jawab diwaktu realisme pengalaman dengan memberi makan yang lapar, memberi pakaian yang telanjang, mengunjungi yang sakit dan di penjara, dengan menemukan nilai belas kasihan. ${ }^{51}$ Oleh karena itu kekristenan menerapkan dalam kehidupan tetap menunjukan dampak menjadi manusia terang dan garam dunia, peduli bagi sesama yang membutuhkan adalah suatu yang membawa kepada Tuhan yang imanen dalam kehadirannya ditengah orang percaya.

${ }^{51}$ Bentley, "Balancing the Transcendence and Immanence of God in Nürnberger's Theology." 


\section{Orang Percaya Mengenal Secara Pribadi Allah Melalui FirmanNya}

Allah menyatakan pribadi-Nya melalui ilham dalam tulisan di Alkitab, supaya setiap manusia dapat mengenal Tuhan dan kehendak-Nya. Allah juga telah menyatakan diri-Nya melalui Anak Tunggal-Nya, yaitu Tuhan Yesus Kristus (Ibr. 1: 1-2; Yoh. 3: 16). Alkitab menyatakan memang tidak ada seorang pernah melihat Allah namun Anak Tunggal Allah, yang ada di pangkuan Bapa, Dialah yang menyatakan-Nya (Yoh. 1: 18). Orang percaya ketika mempelajari firman Tuhan tentang pribadi dan karya Allah membuat orang percaya menghormati dan gentar. Pengenalan akan Allah yang benar membawa kerohanian orang percaya semakin kasih kepada Tuhan, semakin membawa hidup dalam kekudusan dan semakin menaati kehendak Allah dalam kehidupan nyata.

Mengenal lebih jauh tentang Allah dalam terang firman-Nya bukan hanya sekedar untuk menambah ilmu, melainkan membawa orang percaya semakin sungguh-sungguh mengasihi dan semakin berakar, bertumbuh dan berbuah ke arah Kristus Allah yang Imanen. Tuhan yang imanen berarti Tuhan berada di dalam struktur alam semesta serta turut serta mengambil bagian dalam prosesproses kehidupan manusia. Allah yang imanen adalah pribadi yang mau terlibat dan hadir bersama dengan ciptaan-Nya. ${ }^{52}$ Sebab Tuhan menunjukkan imanensiNya, untuk tetap terlibat dalam seluruh keberlangsungan alam semesta. ${ }^{53}$ Hal itu menunjukan bahwa imanensi merupakan kehadiran Allah sebagai Pencipta yang berbeda dengan ciptaan-Nya, sehingga Allah memiliki kontrol dan berdaulat atas

52 John M. Frame, "Introduksi Pada Iman Reformed," Veritas : Jurnal Teologi Dan Pelayanan 8, no. 2 (2007): 169-89, https://doi.org/10.36421/veritas.v8i2.188.

${ }^{53}$ A Kristiadji Rahardjo, "Spiritualitas Kristiani Dan Penyembuhan Psikososial," Media Aplikom 1, no. 2 (2010): 103-22. 
ciptaan. $^{54}$ Orang Kristen berharap mengalami pengaturan kehidupan yang transenden melalui pemeliharaan ilahi melalui imanensi Allah. ${ }^{55}$ Seperti yang dinyatakan oleh Ransford yang dikutip oleh Zaluchu mengatakan bahwa, kehadiran Tuhan secara personal di dalam teologi Kristen dipahami dalam dua sisi sekaligus yakni Allah yang transenden yang ada "di atas" dan yang hidup di dalam iman setiap orang percaya atau disebut imanen. ${ }^{56}$

Dalam teologi Kristen imanen Allah menunjukkan berdiam dan bekerja Allah di dalam seluruh alam semesta, di mana Allah adalah penyebab pertama. Imanen Tuhan sebagai kehadiran-Nya di seluruh alam semesta, karena Tuhan adalah pencipta, namun dalam konsep kehadirannya sering disalahartikan dengan bencana yang terjadi akibat dari kehadiran Tuhan dalam bencana. Memang sejatinya tidak ada tempat di seluruh alam semesta di mana Tuhan tidak hadir. Tuhan hadir dimana-mana, tidak ada tempat di mana Tuhan tidak ada. Tuhan ada di setiap tempat, Tuhan ada dalam segala hal, Tuhan dekat dan jauh pada waktu dan ruang yang sama. Tuhan ada di sini dan di sana pada waktu dan ruang yang sama. Tuhan memenuhi seluruh alam semesta sehingga Dia hadir dalam segala hal, melihat segalanya dan mengendalikan segalanya. Tuhan dekat dengan orang percaya dan terlebih Dia Allah yang imanen.

\section{Orang Percaya Meyakini Allah yang Imanen dan Juga Transenden}

Kehadiran Allah sangat erat terkait sifat Allah yang Maha Hadir (omnipresent). Dalam Perjanjian Lama kitab Mazmur 139: 1-10 menekankan hubungan kedua sifat Allah dalam detail yang indah. Bahkan dalam kitab-kitab

\footnotetext{
54 Frame, "Introduksi Pada Iman Reformed."

55 Webster, "The Immanence of Transcendence: God and the Devil on the Aberdeenshire Coast."

${ }^{56}$ Sonny Zaluchu, "Manifestasi Kehadiran Tuhan Di Dalam Teologi Kristen: Dari Tabernakel Musa Ke Bait Allah Yang Hidup," Khazanah Theologia 3, no. 1 (January 30, 2021): 25-34, https://doi.org/10.15575/kt.v3i1.11158.
} 
Perjanjian Baru, rasul Paulus menyatakan bahwa Allah memberikan hidup dan nafas serta segala sesuatu kepada semua orang dan di dalam Allah orang percaya hidup, bergerak dan ada (Kis. 17: 25, 28). Allah hadir untuk menuntun, mengendalikan dan memelihara ciptaan-Nya, meskipun Allah berada jauh di atas ciptaan. Imanen Allah merujuk kepada kehadiran Allah yang menyatakan kedekatan Allah dengan ciptaan-Nya dan terlibat aktif di dalam pemeliharaan kelangsungan hidup. Setiap pribadi yang diciptakan Tuhan mengalami kehadiran Allah secara nyata, sebab Tuhan merupakan pribadi yang personal. ${ }^{57}$ Imanensi sejatinya menunjuk kepada peran Allah yang peduli kepada manusia dan tidak pernah meninggalkan ciptaan tangan-Nya. Jadi Allah sebagai pribadi yang mengikat janji kepada manusia adalah pribadi yang senantiasa berelasi dengan ciptaan-Nya. ${ }^{58}$

Keberadaan pesan Tuhan dalam Alkitab membuktikan ketertarikan Tuhan akan kosmos atau dunia dan segala perbuatan Allah di dalam rancangan-Nya di dunia. Selain itu, di sepanjang perjalanan kisah historis Alkitab melihat keterkaitan antara penyertaan Tuhan dalam kelangsungan hidup terhadap bangsa pilihan Tuhan. Namun, pembuktian terhadap arti kehadiran dan keterlibatan Tuhan di dalam kosmos adalah melalui inkarnasi Yesus (Lih. Ibr. 1: 3). Yesus adalah Imanuel (Allah beserta kita). Yesus adalah Allah imanen, konsep Kekristenan bahwa imanensi adalah kehadiran Allah pada manusia melalui Kehadiran Yesus Kristus hal ini membuktikan bahwa keberadaan Tuhan, dianalisis dalam arti pentingnya nama "Imanuel", nama yang diberikan kepada

57 Andry Setiawan, "Apologetika Prasuposisional Triperspektivalisme John M. Frame Dan Aplikasinya Terhadap Pemikiran Kristen Pluralis Tentang Pluralisme Agama Di Indonesia," Veritas: Jurnal Teologi Dan Pelayanan 17, no. 1 (2018): 61-80.

58 Frame, "Introduksi Pada Iman Reformed." 
Yesus Kristus. Yesus Kristus, Anak Allah dan Anak Manusia, memiliki sifat ilahi dan manusia, Tuhan yang berinkarnasi, yang mengambil rupa manusia. Melalui Yesus manusia dapat memiliki visi tentang karakter Tuhan. Kehadiran Yesus Kristus di bumi menandakan imanen ilahi. ${ }^{59}$

Tuhan juga adalah pribadi yang imanen yaitu pribadi yang menyatakan diri-Nya secara nyata kepada manusia, pribadi yang dekat dan hadir secara nyata di tengah-tengah manusia dan Tuhan yang berprovidensia serta turut campur tangan dalam segala sesuatu yang terjadi di dalam alam semesta. Manusia dapat datang kepada-Nya di setiap waktu dan tempat. Sifat keberadaan Tuhan ini adalah hal yang tidak dapat dipisahkan. Orang percaya tidak boleh hanya meyakini transendensi Tuhan dan juga tidak boleh hanya meyakini imanen-Nya, karena keduanya adalah sifat penting dari keberadaan-Nya yang diajarkan oleh Alkitab. Kehadiran Tuhan yang membawa perubahan memuncak pada pribadi Yesus Kristus yang hadir ke dalam dunia ini untuk membawa misi kesukaan dan keselamatan. Oleh karena itu hadirnya Yesus membawa perubahan atau menggeser pola-pola lama di dalam Perjanjian Lama mengenai manifestasi Tuhan. Pola-pola dalam Perjanjian Lama bukanlah eksistensi final dari penyataan diri-Nya yang imanen. Hal itu merupakan sebuah tipologi dari inkarnasi Yesus Kristus. ${ }^{60}$ Allah yang dinalar secara rasional dianggap sebagai Allah yang tidak memelihara ciptaan menjadi hal yang bertentangan dengan konsep imanen Allah bagi manusia.

59 ROTARU, "The Name 'Immanuel' = 'God with Us', a Proof of Gods Immanence, According to the Religious Vision of the American Author Ellen G.White."

60 Zaluchu, "Manifestasi Kehadiran Tuhan Di Dalam Teologi Kristen: Dari Tabernakel Musa Ke Bait Allah Yang Hidup." 


\section{KESIMPULAN}

Teologi imanensi menggambarkan Tuhan yang ada, yang di nalar secara logika dan diakui hanya sebagai pribadi yang sama dengan ciptaan-Nya. Walaupun sejatinya Tuhan bekerja melalui hal-hal kecil dari kehidupan ciptaanNya untuk menghasilkan cinta bagi manusia yang berdampak pada mencintai firman Allah dan pribadi Allah sendiri. Oleh karena itu sejatinya keberadaan Tuhan yang transenden dan imanen dapat mengcounter prinsip dari teologi imanensi yang menganggap bahwa Allah dapat dinalar dengan akal dan rasio. Sejatinya imanen mengandung arti bahwa Tuhan sesungguhnya tidak duduk diam dan tidak hanya mengamati ciptaan, namun Alah hadir dan secara aktif berpartisipasi dalam dunia-Nya untuk memberi orang percaya ketenangan dalam pengetahuan bahwa tidak ada tempat atau situasi yang terlalu jauh untuk berada di bawah tangan perlindungan Tuhan. Oleh sebab itu orang percaya bersikap tegas menolak pandangan teologi imanensi. Selanjutnya sikap orang percaya wajib merespon pengenalan akan Allah secara pribadi melalui firman-Nya. Dan juga orang percaya meyakini Allah yang imanen dan juga transenden sebagai kesatuan yang tidak menghilangkan kehadiran Allah dan kemahakuasaan-Nya.

\section{REFERENSI}

Agamben, Giorgio. Absolute Immanence. na, 1999.

Avis, Paul. Ambang Pintu Teologi. 7th ed. Jakarta: BPK Gunung Mulia, 2017.

Bentley, Wessel. "Balancing the Transcendence and Immanence of God in Nürnberger's Theology." Verbum et Ecclesia 39, no. 1 (2018): 1-5.

Chandra, Xaverius. Bahan Ajar Filsafat Ketuhanan. Surabaya: Faculty of Philosophy, 2017.

Dictionary, Dictionary.com is the world's leading digital. "Immanence." 
Dictionary.com, 2021. https://www.dictionary.com/browse/immanence.

Eberle, Harold R. Kekristenan Tanpa Belenggu. Yogyakarta: Yayasan Andi, 2015.

Eckardt, A. "Roy, Menggali Ulang Yesus Sejarah: Kristologi Masa Kini.” Jakarta: BPK Gunung Mulia, 1996.

Erickson, Millard J. Teologi Kristen Volume 1. Malang: Gandum Mas, 2014.

Frame, John M. "Introduksi Pada Iman Reformed." Veritas : Jurnal Teologi Dan $\begin{array}{lllll}\text { Pelayanan } & 8, & \text { no. } & 2 & \text { (2007): }\end{array}$ https://doi.org/10.36421/veritas.v8i2.188.

Ja'far, Suhermanto. "Aku Dalam Tuhan: Implikasi Teologi Proses Pada Era Kontemporer." Ulumuna 16, no. 2 (2012): 347-74.

Johnston, Robert K. "God in the Wasteland: The Reality of Truth in a World of Fading Dreams.” JSTOR, 1995.

Jokhana. "Konsep Transendensi Dan Imanensi Allah Di Dalam Teologi Schleiermacher.” Sekolah Tinggi Teologi Amanat Agung, 2006.

Lane, Tony. Runtut Pijar. Jakarta: BPK Gunung Mulia, 2016.

Lewis Jr, Charles Thomas. "Far and Near: Christian Worship of the Transcendent and Immanent God of Wonders," 2015.

Murnita, Tesra. "Diskursus Transenden Dan Imanen Tuhan Menurut Ibn 'Arabi." UNIVERSITAS ISLAM NEGERI SULTANSYARF KASIM RIAU, 2020.

Rahardjo, A Kristiadji. "Spiritualitas Kristiani Dan Penyembuhan Psikososial." Media Aplikom 1, no. 2 (2010): 103-22.

Ransford, Chris H. "Immanence or Transcendence? A Mathematical View." In Proceedings of Conferences on the Dialogue between Science and Theology, 21-26, 2016. https://doi.org/10.18638/dialogo.2015.2.2.1.

Rey, Kevin Tonny. "Konstruksi Teologi Dalam Konteks Reposisi Pemikiran Warga Gereja." EPIGRAPHE: Jurnal Teologi Dan Pelayanan Kristiani 2, no. 1 (2018): 1-13.

ROTARU, Ioan-Gheorghe. "The Name 'Immanuel' = 'God with Us', a Proof of Gods Immanence, According to the Religious Vision of the American Author Ellen G.White," 2016. https://doi.org/10.18638/dialogo.2015.2.2.3.

Setiawan, Andry. "Apologetika Prasuposisional Triperspektivalisme John M. Frame Dan Aplikasinya Terhadap Pemikiran Kristen Pluralis Tentang 
Pluralisme Agama Di Indonesia." Veritas: Jurnal Teologi Dan Pelayanan 17, no. 1 (2018): 61-80.

Smith, Daniel W. "Deleuze and Derrida, Immanence and Transcendence: Two Directions in Recent French Thought." In The Proceedings of the TwentyFirst World Congress of Philosophy, 11:123-30, 2007.

Suryajaya, Martin. Imanensi Dan Transendensi. Jakarta: Penerbit AksiSepihak, 2009.

Umrati, and Hengki Wijaya. Analisis Data Kualitatif Teori Konsep Dalam Penelitian Pendidikan. Sulawesi Selatan: Sekolah Tinggi Theologia Jaffray, 2020.

Vakili, Hadi. "Fuzzy Epistemology From View Point of Mystical Theology." Kanz Philosophia A Journal for Islamic Philosophy and Mysticism 2, no. 1 (2012): 27-44.

Webster, Joseph. "The Immanence of Transcendence: God and the Devil on the Aberdeenshire Coast." Ethnos 78, no. 3 (September 2013): 380-402. https://doi.org/10.1080/00141844.2012.688762.

Yewangoe, Andreas Anangguru. Allah Mengizinkan Manusia Mengalami Dirinya. Jakarta: BPK Gunung Mulia, 2018.

Zaluchu, Sonny. "Manifestasi Kehadiran Tuhan Di Dalam Teologi Kristen: Dari Tabernakel Musa Ke Bait Allah Yang Hidup.” Khazanah Theologia 3, no. 1 (January 30, 2021): 25-34. https://doi.org/10.15575/kt.v3i1.11158.

Zaluchu, Sonny Eli. "Perkembangan Teologi Kristen Di Dekade Pertama Abad Xxi.” Bunga Rampai Jenis-Jenis Teologi Pada Periode 1990-2009, 2009. 